\title{
THE INFLUENCE OF TEACHER'S INSTRUCTIONAL OBJECTIVES ON VARIATIONS OF EXCHANGE PATTERNS IN AN EFL CLASSROOM
}

\author{
Elis Homsini Maolida \\ School of Postgraduate Studies, Indonesia University of Education, Indonesia \\ email: lisnida_ok@yahoo.com
}

\begin{abstract}
This study investigates how teacher's instructional objectives influence the variations of exchange pattern between teacher and students in their classroom interaction. The present paper tries to find out the variations of exchange pattern in teacher-students interaction and to observe how the teacher's instructional objectives influence those variations. The data were obtained from 90 minutes observation and recording of classroom interaction between a preservice teacher and her students, interview with the teacher, and document analysis. The findings show that the use of exchange patterns in teacher-students interaction varied across learning activities. An exchange pattern dominates a learning activity more than the other. In this case, teacher's instructional objectives provide contexts that guide the teacher to manage the interaction so expected exchanges occur in the class. In other words, the instructional objectives create instructional activities that determine certain exchange patterns to occur through certain methods and strategies. The objectives also influence teacher's strategies in initiating the exchanges, for example in questioning strategies. The domination of non anomalous and synoptic pattern indicates that instructional objectives help the teacher in creating a relatively more manageable interaction in the class. However, it also indicates that the objectives, to certain extent, impede the teacher's initiation in expanding the interaction. This study is expected to raise teachers' awareness to improve their educational planning such as lesson plan and consider some possible negative effects of relying too much on lesson plans. It can also be a reflective description for researchers to put learning objectives into consideration when they analyze classroom interaction.
\end{abstract}

Keywords: instructional objectives, exchange patterns, interaction, lesson plan.

\section{KAITAN TUJUAN PEMBELAJARAN GURU DAN VARIASI POLA INTERAKSI DALAM SEBUAH KELAS BAHASA INGGRIS}

\begin{abstract}
Abstrak: Kajian ini meneliti bagaimana tujuan instruksional guru mempengaruhi variasi pola pertukaran interaksi antara guru dan para siswa dalam interaksi mereka di dalam kelas. Artikel ini mencoba menemukan variasi-variasi pola pertukaran interaksi guru dan siswa dan untuk mengobservasi bagaimana tujuan instruksional guru mempengaruhi variasi-variasi tersebut. Data kajian diambil dari hasil observasi dan rekaman 90 menit interaksi kelas antara guru praktik dan para siswa, wawancara dengan guru, dan analisis dokumen. Hasil kajian menunjukkan bahwa penggunaan pola pertukaran interaksi guru dan siswa bervariasi selama aktivitas belajar. Sebuah pola pertukaran interaksi mendominasi aktivitas belajar dibandingkan dengan yang lainya. Dengan kata lain, tujuan instruksional menciptakan aktivitas instruksional yang menentukan terjadinya pola pertukaran tertentu melalui metode dan strategi tertentu. Tujuan instruksional juga mempengaruhi strategi guru dalam memulai pertukaran, contohnya
\end{abstract}


dalam strategi bertanya. Dominasi pola non-anomali dan sinoptik menunjukkan bahwa tujuan instruksional membantu guru dalam menciptakan interaksi kelas yang relatif lebih mudah ditangani. Namun demikian, tujuan instruksional dalam beberapa hal, dapat menghambat inisiasi guru dalam mengembangkan interaksi. Kajian ini diharapkan mampu meningkatkan kesadaran guru dalam meningkatkan rencanal instruksional mereka seperti rencana pembelajaran dan mempertimbangkan beberapa kemungkinan pengaruh negatif dari terlalu banyaknya mengandalkan rencana pembelajaran. Hal tersebut juga dapat menjadi sebuah penjelasan reflektif bagi para peneliti untuk mempertimbangkan tujuan pembelajaran mereka ketika menganalisis interaksi kelas.

Katakunci: tujuan instruksional, pola-pola pertukaran, interaksi, rencana pengajaran

The importance of objectives as part of lesson plan has been extensively discussed in the literature of teaching. It does not mean that all agree and support on planning the lesson with explicit linear aims. The planning paradox has questioned the emphasis on lesson planning by highlighting that what actually happens in a lesson is a result of more complex interaction that is influenced by what is happening minute by minute between teacher and student (Harmer, 2007). Therefore, planning a lesson with fixed aims might produce teachers who are not aware of the dynamic pattern that occurs in the classroom (Mallow, 2002 cited in Harmer, 2007). Apart from different reactions to lesson planning policy, the fact remains that most teachers do think about what to teach before they interact with their students (Harmer, 2007; Ridell, 2010).

Moreover, for teachers with no or less experience such as pre-service teacher, clear instructional objectives can help them with ideas of what will be done in the lesson. Ridell (2010) shares his experience as a teacher trainer that he can normally predict the quality of the lesson he is about to observe from the quality of the plan which has been handed on.

In Indonesian context, lesson plan that includes explicit objectives is required for teachers, especially those who teach in formal schools. The terms used in creating lesson plan might be different among institutions and teachers but they often refer to the same thing.
As lesson planning becomes one of teacher's obligations, pre-service teachers are also required to submit a detailed lesson plan each time they teach. The next question is, to what extent does the lesson plan influence the way they teach, especially the way they interact with students?

This question is important since the interaction between teacher and students in a language class plays a particularly important role in which the linguistic patterns are the goal as well as the vehicle of instruction. It means that language becomes medium of instruction and learning objectives. For that reason, analysis of classroom interaction needs to be conducted.

The analysis of classroom discourse to answer various research questions has been carried out by some researchers. Stubbs (1996) investigates classroom talk and analyzes it based on its meta-communicative functions that characterize teacher-talk to find some strategies employed by a teacher to keep in touch with his/her pupils. Meanwhile, Kakava (1995) provides a good discussion on directness and indirectness in classroom interactions, viewed from the intersection of contextual and cultural constraint. Regarding the connection between instructional objectives and classroom interaction, Seed-house (1995) points out that the linguistic patterns of interaction in classroom can be linked to the pedagogical purpose by using some methodologies. One of them is through con- 
versation analysis related to the concept of classroom interaction as a rule-governed behavior. This study, then, tries to describe how instructional objectives influence the interaction patterns in the classroom by analyzing conversation in a lesson event.

\section{Classroom Discourse}

Since there are many definitions of discourse, we need to specify how classroom discourse is defined in this research. The term 'discourse' used in this paper takes Ventola (1987) and Martin's (1992) definition that puts discourse as one of three strata on the language plane in a social interaction. More specifically, classroom discourse that we talk about in this paper refers to "... one form of the realization of social interaction, that is, classroom interaction, on the plane of language" (Suherdi, 2003, p.1).

This research focuses on analyzing exchange (which contains one or more moves) and move (minimum contribution by one participant or a turn in conversation). The following figure (Suherdi, 2003) shows how the exchange is categorized in this research.

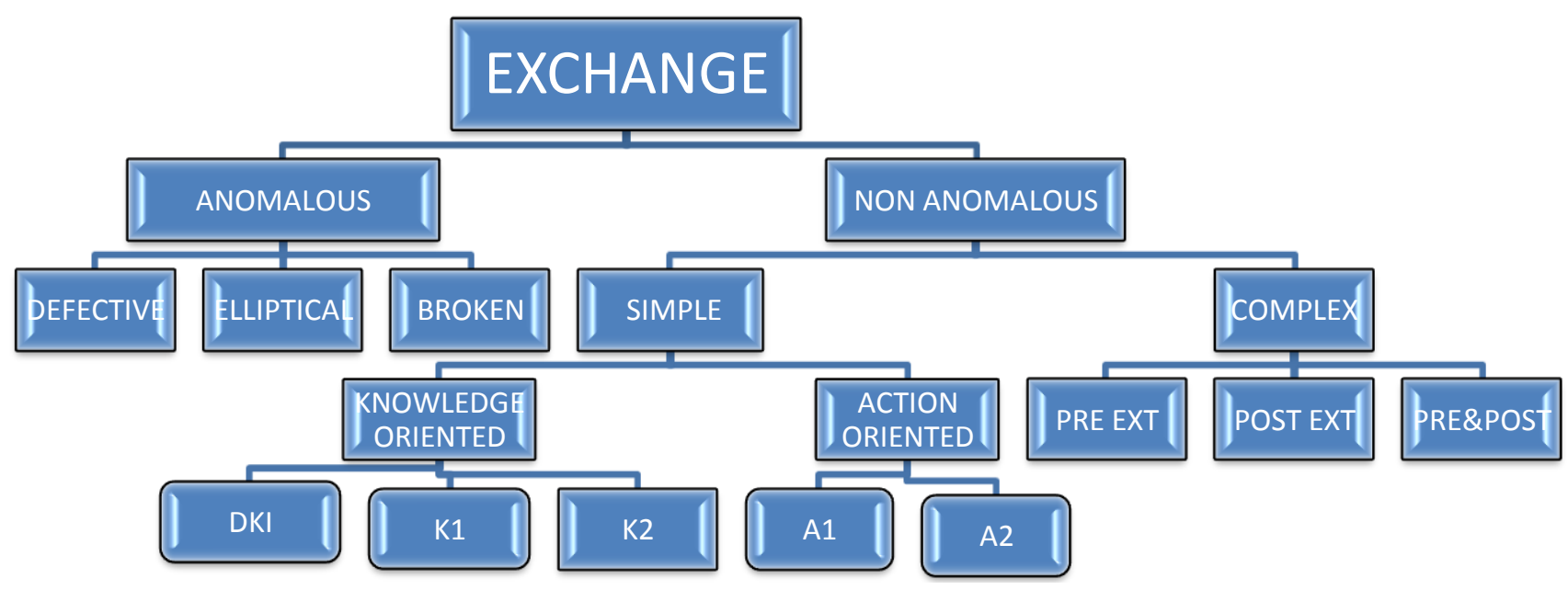

Exchange Categories (Adapted from Suherdi, 2003)

The exchange is divided into two, nonanomalous, predicted exchange, which follow some certain patterns (well-formed exchange) and anomalous, unpredicted exchange that do not fit with the normal pattern of exchanges. The first is divided into simple and complex exchange. Simple exchange, which is constituted by synoptic moves (predicted and well-formed moves) includes knowledge and action oriented exchanges. Knowledge oriented exchanges covers:

1) DKI-initiated pattern: Negotiated exchanges when the primary knower gives question which he/she knows the answer. This kind of question is also commonly known as display question. In classroom context, display question is usually used as a strategy to elicit language practice (Richard and Schmidt, 2002) and negotiate knowledge so the information and knowledge is shared by students via teacher's question. In a study, Roostini (2011) reveals that most teachers, both experienced and inexperienced, tend to use more display than referential question. There are three patterns of DKI:

$\mathrm{DKI} \mathrm{I}^{\wedge} \mathrm{K} 2^{\wedge} \mathrm{K} 1$

$\mathrm{DKI} I^{\wedge} \mathrm{K} 2^{\wedge} \mathrm{K} 1^{\wedge} \mathrm{K} 2 \mathrm{f}$

$\mathrm{DKI} 1^{\wedge} \mathrm{K} 2^{\wedge} \mathrm{K} 1^{\wedge} \mathrm{K} 2 \mathrm{f}^{\wedge} \mathrm{K} 2 \mathrm{f}$

2) K1-initiated pattern: Non-negotiated exchange when the primary knower directly presents the knowledge or information. Some people recognize it as lecturing method used by a teacher in the 
class. Jariyah and Neti (2012) show that lecturing is less effective to be applied when students need to analyze, integrate and synthesize knowledge but is appropriate for clarifying an issue, sharing personal experience, modeling a procedure (Pascal, 1983 in Jariyah and Neti, 2012), and communicating a lot of material to a large number of students in a short period of time (McKeachie \& Kulik, 1975). There are three patterns of $\mathrm{K} 1$ :

$\mathrm{K} 1$

$\mathrm{K} 1 \wedge \mathrm{K} 2 \mathrm{f}$

$\mathrm{K} 1^{\wedge} \mathrm{K} 2 \mathrm{f}^{\wedge} \mathrm{K} 1 \mathrm{f}$

3) K2-initiated pattern: The first speaker is the secondary knower, for example when a teacher gives students referential question (the asker does not know the answer). Different from the function of display question in DKI pattern, the purpose of using referential question in $\mathrm{K} 2$ pattern is to seek information (Richard and Schmidt, 2002). This type of question is said to be applied in higher level class and more effective in stimulating learners' language and critical thinking (Thornbury, 1996). Another benefit of using referential question is that students who are taught with more referential questions give significantly longer and more syntactically complex responses to the questions (Nunan, 1998), for example in gaining students' elaboration by probing their opinion (Hidayat and Aisyah, 2010). There are several patterns of $\mathrm{K} 2$ :

$\mathrm{K} 2^{\wedge} \mathrm{K} 1$

$\mathrm{K} 2^{\wedge} \mathrm{K} 11^{\wedge} \mathrm{K} 2 \mathrm{f}$

$\mathrm{K} 2^{\wedge} \mathrm{K} 1^{\wedge} \mathrm{K} 2 \mathrm{f}^{\wedge} \mathrm{K} 1 \mathrm{f}$

Action oriented exchanges (Realizing action-oriented rather than knowledgeoriented exchanges) consist of: (1) A1initiated patterns, in which the first speaker performs verbal or non verbal actions such as teacher gives example of English expressions or writing something on the whiteboard, and (2) A2-inititaed patterns, in which the first speaker asks the second speaker to perform something such as teacher asks students to read a text or move the chair in the class.

Complex exchange is the exchange that is constituted by synoptic and dynamic moves (Suspending, aborting, elucidating and sustaining moves) that appear in certain exchanges when the exchange is not as smooth as the synoptic move. It is divided into three categories: (1) Pre-inform extended exchanges contains any dynamic moves before the informing moves, (2) Post-inform extended exchanges contain any dynamic moves after the informing moves, and (3) Pre and post-inform extended exchanges contain any dynamic moves before and after the informing moves.

Anomalous is unpredicted exchanges that do not fit with the normal pattern of exchanges. It is divided into three types: (1) Elliptical exchange, in which $\mathrm{K} 1$ is absent since the true answer is known by almost all interactants, (2) Defective exchange, in which $\mathrm{K} 2$ is absent and it usually happens when teacher's question gets no answer since the students do not know the answer so that the teacher decides to answer his/her own questions, and (3) Broken exchange, in which the exchange that is abandoned, when the teacher asks something and the students ignore/give no response. One of teacher's decisions is by aborting the question by moving to another topic.

\section{Instructional Objective}

The term 'instructional objectives' used in this paper refers to what Reiser and Dick (1989, p.23) define as explicit descriptions of what students will be able to do as a result of the instruction they receive. The objectives also help teachers to focus upon the outcomes of instruction and enable them to recognize whether their students have attained those outcomes. Therefore, the objectives here do not only refer to general competencies that the 
students should accomplish but also the objectives of each lesson stage.

In Indonesian context, teachers sometimes use different terms for lesson stage. Some divides a lesson event into three main stages: opening, main activity and closing. The others describe the stages of lesson in a more detailed description of main activities using some terms such as exploration, elaboration, and confirmation stage. The researchers also use different terms to explain lesson stages which suit their research questions, such as Suherdi (2008) who describes the scaffolding process in GBA model by using four stages of the curriculum cycle, including developing control of the genre, modeling the text type, joint construction, and independent construction of text. In this paper, lesson stages will be divided into 3 main stages: opening, main activities (which are divided into four sub activities that represents the shift of teachers instructions to attain specific objectives), and closing.

\section{Pedagogical Purposes and Interaction Patterns}

Teachers can get several benefits of explicitly stating what they want students to gain from the lesson. Brown (2001, p. 150) has listed those advantages: (1) We know what we want to accomplish, (2) We can preserve the unity of our lesson, and (3) We can evaluate students' success at the end of lesson. That is why inexperienced teachers such as new teachers, teacher trainees, and pre-service teachers are often required to submit a detailed lesson plan each time they teach to help them manage classroom interaction well. For more experienced teachers, they may plan the lesson in a less detailed procedure. The point is, it is inevitable for teachers to have objectives before having interaction with students (Ridell, 2010; Harmer, 2007).

Regarding the use of planning in attaining the objectives in the class, Harmer (2007, p.366) suggests that teachers should modify the activities when several moments take place during classroom interaction such as magic moments, sensible diversion and unforeseen problems. The flexibility of time is also essential (Ridell, 2010) so the teachers need to take on-the spot decisions looking at how the students are reacting to what they say and deliver in the class.

Relating to the influence of instructional objectives on teacher-student interaction Seedhouse (1995) points out that when teacher introduces a learning activity in classroom, he also introduces some communication patterns, which should be followed by the students. It is supported by Shimanoff's (1980) who states that in language classroom pedagogical purposes can, to some extent, also be equated to communication rules. Brown (2001) also reminds us about the importance of balancing student talk and teacher talk since the natural inclination is teacher dominating the interaction. In a language class, students producing language becomes the core of lesson since language is used as materials, targets and interaction tool in the classroom.

The shift of orientation in curriculum (and objectives) is also an important aspect that links the objectives to the way teacher and students interact in the classroom. Suherdi (2008) gives a brief explanation on how the shift from knowledge-based to skill-oriented teaching that takes place in Indonesian context (TEFLIN) increases the actual English performance in the class. Consequently, the nature of interaction also changes as the students need to have more active practice of communicating in English.

\section{METHOD}

This research is a descriptive qualitative one involving a speech event, which was a 90 minute-English lesson. The teacher was a pre-service teacher who was assigned to teach English to grade 11 in a senior high school in Bandung. As a pre-service teacher, she had a 
responsibility to plan the lessons carefully since the lesson would be observed, evaluated and scored. Hence, all things related to her teaching were well documented.

The data were collected from observing and recording an EFL classroom interaction with permission from institutional officials. The teacher was also interviewed. The interview focused on checking the result of transcription and confirming the results of the analysis. In addition, the researcher analyzed related documents to analyze the instructional objectives that were assumed to have a link to the variations of exchange patterns in teacherstudents interaction.

The data were coded by using Suherdi's categorization of exchange $(2003 ; 2008)$. The result of observation and note taking were also taken to support the data, including non-verbal interaction. Then the data were distributed based on the stages of the lesson and the focus of teacher's instructional objectives in lesson plan. After that, the interpretation was taken focusing on specific aspects related to the aims of the research.

\section{FINDINGS AND DISCUSSION}

To find the variations of exchange patterns in teacher-students interaction and the influence of instructional objectives on variations of exchange pattern in classroom interaction, several tables will be displayed to show the distribution of exchanges and see which exchange dominates a learning stage and how it reflects instructional objectives:

\section{The Distribution of Exchanges across Learning Stages}

As mentioned above, the categorization of exchanges was in accordance with the categories applied by Suherdi (2003; 2008). Table 1 shows the first finding. In Table 1, all exchanges are coded and divided into two: non-anomalous (predicted exchanges following normal pattern) and anomalous (unpredicted exchanges that do not fit with the normal pattern of exchanges). Then, non anomalous exchanges are categorized into knowledge and action-oriented exchanges, based on first interactant's orientation when he/she initiates the exchange.

There are 106 exchanges identified in classroom interaction. Of these 106 exchanges, $92(86.79 \%)$ are non-anomalous exchanges and only $14(13,21 \%)$ are anomalous exchanges. It shows that the interaction takes place mostly in predicted way. This is to say that the interaction in the class has been planned well or at least, the teacher tries to manage the interaction in accordance with instructional objectives.

Table 1-The distribution of exchange patterns across learning stages

\begin{tabular}{lllllllll}
\hline $\begin{array}{l}\text { EXCHANGE } \\
\text { PATTERNS }\end{array}$ & & Opening & $\begin{array}{l}\text { 1st } \\
\text { Activity }\end{array}$ & $\begin{array}{l}\text { 2nd } \\
\text { Activity }\end{array}$ & $\begin{array}{l}\text { 3rd } \\
\text { Activity }\end{array}$ & $\begin{array}{l}\text { 4th } \\
\text { Activity }\end{array}$ & Closing & Total \\
\hline \multirow{2}{*}{$\begin{array}{l}\text { Non }- \\
\text { anomalous }\end{array}$} & $\mathrm{k}$ & 2 & 12 & 16 & 18 & 8 & 4 & 72 \\
& $\begin{array}{l}\text { sub } \\
\text { total }\end{array}$ & 16 & 19 & 19 & 20 & 14 & 4 & 92 \\
Anomalous & & 6 & 0 & 4 & 2 & 0 & 2 & 14 \\
Total & 22 & 19 & 23 & 22 & 14 & 6 & 106 \\
\hline
\end{tabular}


This description is supported by the findings that simple synoptic exchanges dominates (66 exchanges or $71.74 \%$ ) the interaction, compared to complex exchanges (26 exchanges or $28.26 \%$ ). When this was confirmed, the teacher admits that she tried to manage the interaction in such a way so all objectives can be attained in a limited time slot. Another interesting finding that shows how instructional objectives control the teacher's decision to expand or end an exchange is shown by an elliptical exchange below:

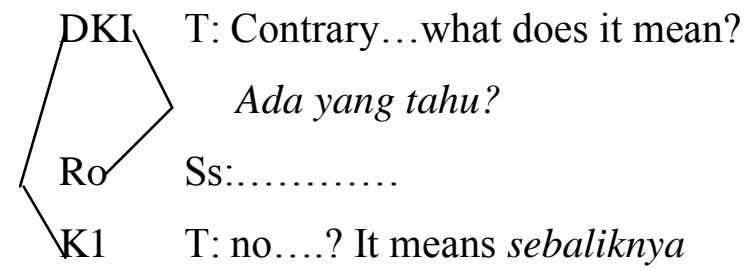

Getting no response from the students, the teacher decided to answer the question herself. Confirmation reveals that she did that because the content of the exchange was not the focus of objective. The main objective for that stage was for students to be able to complete the dialogue about like and dislike. It shows that the teacher tends to shorten the interaction in an exchange that had no direct relation to objectives in that lesson stage. The distribution of knowledge and action oriented exchanges will be discussed in the next section.

\section{The distribution of knowledge oriented exchange patterns}

In Table 2, the exchanges are distributed into three categories (Suherdi, 2003, 2008): DKIinitiated pattern, K1-initiated pattern and K2 initiated pattern. We can find which pattern dominates interaction in the class and in which lesson stage it happens and how the instructional objectives influence those patterns.
The following is the simplified distribution of knowledge oriented exchanges across learning activities:

1. DKI-initiated pattern:

$3^{\text {rd }}$ sub activity (16) $>2^{\text {nd }}$ sub activity (7) $>4^{\text {th }}$

sub activity (3)>closing (1)>opening

$(0)=1^{\text {st }}$ sub activity $(0)$

2. K2-initiated pattern:

Opening (12) $>1^{\text {st }}$ sub activity (7) $>2^{\text {nd }}$ sub activity (6) $>3^{\text {rd }}$ sub activity (1)=closing (1) $>4^{\text {th }}$ sub activity $(0)$

3. K1-initiated pattern:

$4^{\text {th }}$ sub activity (5) $>1^{\text {st }}$ sub activity (4) $>2^{\text {nd }}$ sub activity (4(>closing (3)>opening (2) $>3^{\text {rd }}$ sub activity (1)

From Table 2, 72 knowledge oriented (KO) exchanges are identified. Of these 72 KO exchanges, 19 are K1 initiated patterns, 26 DKI initiated patterns, and $27 \mathrm{~K} 2$ initiated patterns. The distribution shows that the number of DKI and K2 patterns is higher than $\mathrm{K} 1$. It indicates that the teacher applies more negotiated knowledge in the interaction by using questioning strategies (display and referential questions) so information can be shared among students via teacher's questions and minimizes lecturing method (K1). The teacher confirmed that this is in line with her objectives for students to get communicative competence of speaking and listening so she tried to use question and answer instead of lecturing method. The teacher also admitted that her supervisor suggested her to give more opportunities for student to talk and practice their communicative skills in the class $(70 \%$ students talk and 30\% teacher talk are suggested). Therefore, the high number of DKI and K2 patterns is influenced by teacher's objectives for students to give them more opportunities to perform the language. Hence, the objectives create context in which certain interaction patterns are expected to occur (Seedhouse, 1995). Now we will see in which stage a certain pattern dominates interaction. 
Table 2: The distribution of knowledge oriented exchange patterns

\begin{tabular}{|c|c|c|c|c|c|c|c|c|}
\hline \multicolumn{2}{|c|}{$\begin{array}{l}\text { Exchange } \\
\text { patterns }\end{array}$} & \multirow{2}{*}{$\begin{array}{l}\text { opening } \\
2\end{array}$} & \multirow{2}{*}{$\begin{array}{l}1^{\text {st }} \text { activity } \\
4\end{array}$} & \multirow{2}{*}{$\frac{2^{\text {nd }} \text { activity }}{4}$} & \multirow{2}{*}{$\frac{3^{\text {rd }} \text { activity }}{1}$} & \multirow{2}{*}{$\frac{4^{\text {th }} \text { activity }}{4}$} & \multirow{2}{*}{$\begin{array}{l}\text { closing } \\
3\end{array}$} & \multirow{2}{*}{$\begin{array}{l}\text { total } \\
18\end{array}$} \\
\hline & $\mathrm{s}$ & & & & & & & \\
\hline \multirow[t]{3}{*}{ K1 } & $\mathrm{c}$ & - & - & - & - & 1 & - & 1 \\
\hline & sub total & 2 & 4 & 4 & 1 & 5 & 3 & 19 \\
\hline & $\mathrm{s}$ & - & - & 5 & 4 & 1 & 1 & 11 \\
\hline \multirow[t]{3}{*}{ DKI } & $\mathrm{c}$ & - & - & 1 & 12 & 2 & - & 15 \\
\hline & sub total & - & - & 6 & 16 & 3 & 1 & 26 \\
\hline & $\mathrm{s}$ & 10 & 7 & 5 & - & - & - & 22 \\
\hline \multirow[t]{2}{*}{ K2 } & $\mathrm{c}$ & 2 & 1 & 1 & 1 & - & - & 5 \\
\hline & sub total & 12 & 8 & 6 & 1 & - & - & 27 \\
\hline total & & 14 & 12 & 16 & 18 & 8 & 4 & 72 \\
\hline
\end{tabular}

K1 patterns dominate opening stage in which teacher motivates, leads, and links students' interest and background knowledge to the main topic. The teacher used referential questions that seek the information (Richard and Schmidt, 2002) and let students share their personal experience related to like and dislike. We can see now how the objective influence the way teacher initiates the exchange by using referential question so the students can produce language that lead them to the main objective. The following excerpts are two examples:

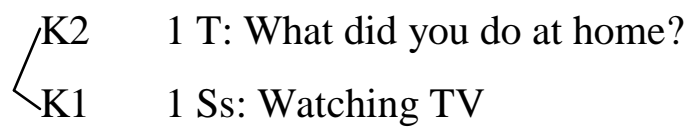

K2 1T: Speaking about watching television, does any of you..

2 Did any of you watch a..er, the football match?

K1 Ss: Yes, yes, of course, of course (most are the boys' voice)

The teacher did not evaluate students' answer as her objective was not to elicit correct answer, but to motivate students and link their background knowledge and personal experience to the topic about like and dislike by probing students' opinion (Hidayat\& Aisyah, 2010). DKI pattern dominates $3^{\text {rd }}$ sub activity which has the objective for students to identify like and dislike expressions in formal and informal context as an indicator of mastering one of the basic competencies. By using display question, the teacher elicited students' responses (Richard and Schmidt, 2002) to give examples of like and dislike 
expressions from the students as shown by the following excerpt:

(The teacher collects expressions of like and dislike from a dialogue text)

$\begin{cases}\text { DKI } & \text { T: What else? } \\ \text { Check } & \text { S11: I don't like } \\ \text { T: What is it? } \\ \text { Is it expressions } & \text { Ss: dislike... } \\ \text { K1 } & \text { T: Very good! }\end{cases}$

The use of display question is influenced by the objective for students to identify the expressions from the text. This is a typical type of questions used by most teachers to elicit responses from student to be evaluated (Roostini, 2011).

Even though the number of $\mathrm{K} 1$ is less significant comparing to DKI and $\mathrm{K} 2$, the fact that $\mathrm{K} 1$ dominates certain lesson stage needs further explanation to find its link to instructional objective. $\mathrm{K} 1$ dominates $4^{\text {th }}$ activity which has objective for students to perform a dialogue in group. This excerpt is one of the examples:

-K1 1 Now, we still have time

2 Since you have understood the usage, er...of like and dislike

$3+$ and then you also find some new expressions other than that we have found in the dialogue

$\mathrm{K} 1$ here is used to recap what has been done in the previous stage to prepare for new learning stage and explain simple procedure (Pascal, cited in Jariyah and Neti, 2012) that support action-oriented move.

\section{The distribution of action oriented exchange patterns}

In Table 3, the exchanges are distributed into two categories (Suherdi, 2003): A1-action oriented pattern and A2-action oriented pattern. We can find which pattern dominates interaction in the class and in which lesson stage it happens and how the instructional objectives influence those patterns.

The following is the simplified distribution of action oriented exchanges across learning activities:

1. A1-initiated pattern

$1^{\text {st }}$ sub activity (5)>opening (2) $=1^{\text {st }}$ sub activity (2) $=3^{\text {rd }}$ sub activity (2) $>4^{\text {th }}$ sub activity $(0)=$ closing $(0)$

2. A2-initiated pattern

$4^{\text {th }}$ sub activity $(5)>1^{\text {st }}$ sub activity (2) $>2^{\text {nd }}$ sub activity (1)>opening (0) $=3^{\text {rd }}$ sub activity $(0)=$ closing $(0)$

From Table 3, 20 action-oriented exchanges are identified. Of these 20 exchanges, 12 are A1 action oriented patterns (The first speaker performs verbal or non verbal actions) and 8 A2 initiated patterns (The first speaker asks the second speaker to perform something). The distribution shows that the number of $\mathrm{A} 1$ exchanges is higher than A2. It indicates that the teacher performed more actions to support the learning process such as writing on the board (non verbal), playing the tape (non-verbal), or reading the text (verbal) to achieve the objectives of learning. It can be seen from stage in which the domination of A1 occurs. 
Table 3: The distribution of action oriented exchange patterns

\begin{tabular}{|c|c|c|c|c|c|c|c|c|}
\hline \multicolumn{2}{|c|}{$\begin{array}{l}\text { Exchange } \\
\text { Patterns }\end{array}$} & \multirow{2}{*}{$\begin{array}{l}\text { Opening } \\
2\end{array}$} & \multirow{2}{*}{$\begin{array}{l}1^{\text {st }} \\
\text { Activity } \\
5\end{array}$} & \multirow{2}{*}{$\begin{array}{l}2^{\text {nd }} \\
\text { Activity } \\
-\end{array}$} & \multirow{2}{*}{$\begin{array}{l}3^{\text {rd }} \\
\text { Activity } \\
2\end{array}$} & \multirow{2}{*}{$\begin{array}{l}4^{\text {th }} \\
\text { Activity } \\
1\end{array}$} & \multirow{2}{*}{$\begin{array}{l}\text { Closing } \\
-\end{array}$} & \multirow{2}{*}{$\begin{array}{c}\text { Total } \\
10\end{array}$} \\
\hline & $\mathrm{s}$ & & & & & & & \\
\hline \multirow[t]{3}{*}{ A1 } & $\mathrm{c}$ & - & - & 2 & - & - & - & 2 \\
\hline & sub total & 2 & 5 & 2 & 2 & 1 & - & 12 \\
\hline & $\mathrm{s}$ & - & 2 & 1 & - & 2 & - & 5 \\
\hline \multirow[t]{2}{*}{$\mathrm{A} 2$} & $\mathrm{c}$ & - & - & - & - & 3 & - & 3 \\
\hline & sub total & - & 2 & 1 & - & 5 & - & 8 \\
\hline \multicolumn{2}{|c|}{ total } & 2 & 7 & 3 & 2 & 6 & 0 & 20 \\
\hline
\end{tabular}

A1 pattern dominates $1^{\text {st }}$ sub activity which has objective for students to complete the dialogue from the tape as an indicator of understanding the dialogue about like and dislike. It influences teacher's actions to create context that lead to the occurrence of expected response. The following is one of the examples:

$\left[\begin{array}{ll}\mathrm{A} 1: \mathrm{V} & \mathrm{T}: \mathrm{I} \text { will, er..play the tape } \\ \mathrm{A} 1: \mathrm{NV} & \text { (Teacher prepare and play the }\end{array}\right.$
tape)

A2 pattern dominates $4^{\text {th }}$ sub activity that has objective for students to perform dialogue about like and dislike. The objective influences teacher's initiation that leads to expected responses from students. The following excerpt is one of examples:

\begin{tabular}{l} 
A2 \\
Irr \\
$A 1$ \\
\hline
\end{tabular}

T: Next group?

SS: Hatta..Hatta..

S12: Hi guys, Do you know Bangsal 13 movie?

S13: Oh yes

S15: No, I have not seen it

S14: What do you think about the movie?

S12: Wow! I really like that. It's very scared me

S13: I don't think so

S15: Why?

S13: Because..is so boring. I hate that

S15: Oh, you make me want to see that movie. Let's go

S12+13: Ok..go..go..go

A2f T: Ok, short but nice

Ok, good

From the examples of excerpt taken from different lesson stage, we can see that instructional objectives influence teacher's move initiation, teacher's decision to create contexts which enable expected response to occur. Since the teacher's initiation also 
influences the way student respond, we can agree with Shimanoff's (1980) statement that in language classroom pedagogical purposes are, to some extent, communication rules.

\section{The distribution of exchange patterns within learning activities}

The result of coding, categorization and distribution shows that the variations of exchange pattern vary within learning stages. An exchange pattern dominates a learning activity more than the other. The following are the variations of exchange pattern within learning stage. The first pattern of opening stage is $\mathrm{K} 2=12>\mathrm{K} 1=2>\mathrm{DKI}=0$ and $\mathrm{A} 1=2>\mathrm{A} 2=0$

The fact that $\mathrm{K} 2$ exchange dominates the opening stage reflects the objective of this stage for students to share their personal experience and link their background knowledge to the topic of like and dislike. It is in line with a research by Suherdi (2003) in describing GBA model that $\mathrm{K} 2$ is dominant in the lesson which focuses on establishing the context of shared experience. In this stage, teacher utilizes referential questions to obtain the objective and serve the function as secondary knower so the students are more confident serving as primary knower in sharing their personal experience and background knowledge. The pattern for $1^{\text {st }}$ sub-activity is $\mathrm{K} 2=7>\mathrm{K} 1=4>\mathrm{DKI}=0$ and $\mathrm{A} 1=6>\mathrm{A} 2=2$

In this activity the exchange pattern that has significant number is k2-initated pattern and A1 initiated exchanges. This stage is unique in which action oriented appears in significant number. It reflects the objective of this $1^{\text {st }}$ sub activity for students to complete the blanks in the dialogue based on the dialogue in the tape. To achieve the objective, the teacher performs frequent actions of preparing, playing, pausing, replaying and turning off the tape, also spreading the paper for students.
The domination of $\mathrm{K} 2$ in listening session supports the objective. The teacher used referential question to assure whether the students follow and comprehend the dialogue (regarding the voice clarity of the tape) and use $\mathrm{K} 2$ move initiation to build rapport by asking student' opinion about the speakers in the tape. The pattern for $2^{\text {nd }}$ sub activity is $\mathrm{DKI}=7>\mathrm{K} 2=6>\mathrm{K} 1=4$ and $\mathrm{A} 1=2>\mathrm{A} 2=1$

The domination DKI pattern reflects the objective of $2^{\text {nd }}$ sub activity for students to identify like and dislike expressions from the dialogue. The strategy of using display question is used to get the answer from students. It is obvious that the teacher intends to evaluate students' comprehension and put her position as the primary knower. The teacher confirms that she usually gives display questions when the activities are related to language focus. The pattern of $3^{\text {rd }}$ sub activity is $\mathrm{DKI}=16>\mathrm{K} 2=1=\mathrm{K} 1=1$ and $\mathrm{A} 1=2>\mathrm{A} 2=0$

In this stage the teacher tries to elicit like and dislike expressions from students by using displayed questions (DKI=16) instead of giving information directly about various kinds of like and dislike expressions (K1). It reflects the objective of $3^{\text {rd }}$ sub activity for student to discuss like and dislike expressions and give examples of their own. The domination of DKI pattern seems to combine giving information, practice and feedback. By collecting like and dislike expressions from students using DKI move initiation, the teacher gives the correct information to the whole class by using ask-answer-evaluation method. Through DKI exchange, the teacher gives evaluation or feedback after the answer while in the same time provides students opportunity to practice the language in the class. The following is the exchange pattern of $4^{\text {th }}$ sub activity: $\mathrm{K} 1=5>\mathrm{DKI}=3>\mathrm{K} 2=0$ and $\mathrm{A} 2=6>\mathrm{A} 1=0$

In this activity, the teacher asked the students to perform a dialogue $(\mathrm{A} 2=6)$ and evaluated the performance. Since this activity focuses on students speaking performance, the 
teacher applies A2 initiation to ask students to write the script and perform it in front of the class. The frequent occurrence of $\mathrm{K} 1$ is utilized to explain procedure so the objectives can be attained. The distribution of exchange pattern in closing stage: $\mathrm{K} 1=4>\mathrm{K} 2=1=\mathrm{DKI}=1$ and $\mathrm{A} 2=\mathrm{A} 1=0$

This activity focuses on summarizing what students have learned and closing the session. The domination of $\mathrm{K} 1$ reflects the objective for students to recap what they have learned. By initiating K1 move, the teacher puts herself as the primary knower. She decided to inform students directly to clarify an issue (Jariyah and Neti, 2012) and sum up a lot of factual material to a large number of students in a short period of time (McKeachie \& Kulik, 1975).

\section{CONCLUSION}

The findings of the research reveal that the use of exchange patterns in teacher-students interaction varied across learning activities. An exchange pattern dominates a learning activity more than the other. The patterns

\section{REFERENCES}

Brown, H. D. (2001). Teaching by principles: An interactive approach to language pedagogy. New York: Longman

Harmer, J. (2007). The practice of English language teaching. England: Pearson Education

Hidayat, D. R. \& Aisah, E. E. (2010). Teacher strategies in initiating esl young learners to speak English. Paper presented at The $3^{\text {rd }}$ International Conference on Applied Linguistics (CONAPLIN). Bandung: Indonesia University of Education (UPI)

Jariyah, A. \& Neti. (2012). The use of questioning strategy in lecturing mode of learning. Unpublished paper.

Kakava, C. (1995). Directness and indirectness in professor-student interactions: The intersection of contextual and cultural constraints. In reflect the objectives of the learning stage. In this case, teacher's instructional objectives provide contexts that guide the teacher to manage the interaction so the expected exchanges occur in the class. In other words, the instructional objectives create instructional activities that determine certain exchange patterns to occur through certain methods and strategies. Hence, the objectives, to certain extent, are communication rules in classroom language. The objectives also influence teacher's strategies in initiating the exchanges, for example in questioning strategies. The domination of non anomalous and synoptic pattern indicates that instructional objectives help the teacher in creating a relatively more manageable interaction in the class. However, it also indicates that the objectives, to certain extent, impede the teacher's initiation in expanding the interaction especially with teacher's choice to end an exchange instead of expanding and scaffolding it when the content of exchange is not considered as language focus of the lesson and due to time limitation.

\section{Alatis, J.E (ed). Georgetown University Round Table on Language and Linguistics. Washington DC: Georgetown University}

Martin, J.R. (1992). English text: System and structure. Amsterdam: John Benjamins Publishing Company, (Chapter 7).

McKeachie, W.J. \& Kulick, J.A. (1975). Effective college teaching. In F.N Kerlinger (ed). Research in education, 3.Tiasca, IL: Peacock Press.

Nunan, D. (1998). Language teaching methodology. Edinburgh: Pearson Education Limited

Reises, R,A \& Dick, W. (1989). Instructional planning: A guide for teachers. USA: Allyn and Bacon Richards, J.C., \& Schmidt, R.W. (2002). Longman dictionary of language teaching and applied linguistics ( $\left.3^{\text {rd }} \mathrm{ed}\right)$. London: Pearson Education 
Riddell, D. (2010). Teach EFL. United States: McGraw-Hill Companies, Inc.

Roostini, K E. (2011). A Reflection on Teacher Questioning Types. Conaplin Journal: Indonesian Journal of Applied Linguistics, 1(1), pp. 10-23.

Shimanoff, S. (1980). Communication rules. Beverly Hills: Sage.

Seedhouse, P. (1995). L2 classroom transcripts: Data in search of a methodology?, TESL-EJ, 1(4) 1(4), A-1.

Stubbs, Michael. (1983). Discourse analysis. the sosiolinguistic analysis of natural language. England: Basil Blackwell Ltd.

Suherdi, D. (2012). The use of quality pedagogic language in the teaching of English in indonesian setting. EDUCARE:International Journal for Educational Studies, 4 (2), pp. 111-124

Suherdi, D. (2008). Scaffolding in Junior High School (SMP) English teaching-learning process. Paper Presented at The International Conference on Applied Linguistics 1, pp. 11-12 Bandung: Universitas Pendidikan Indonesia

Suherdi, D. (2003). Discourse analysis in classroom research: A systemiotic perspectives. Bandung: English Department, Indonesia University of Education

Suherdi, D. (1998). Perananan analisa diskursus in refleksi terhadap kegiatan belajar mengajar bahasa. In Alwasilah, A. C. (eds). Bunga rampai pengajaran bahasa. Bandung: CV Andira.

Thornbury, S. (1996). Teachers research teacher talk. ELT Journal, 50(4), pp. 279289. doi: 10.1093/elt/50.4.279

Ventola, E. (1987). The structure of social interaction: A systemic approach to the semiotics of service encounter. London: Frances Pinter, pp. 75-78. 